\begin{tabular}{|l|l|l||}
\hline \multicolumn{2}{|c|}{ PublisherInfo } \\
\hline \hline PublisherName & $:$ & BioMed Central \\
\hline \hline PublisherLocation & $:$ & London \\
\hline \hline PublisherImprintName & $:$ & BioMed Central \\
\hline \hline
\end{tabular}

\title{
A new defense alliance
}

\begin{tabular}{|l|l|l||}
\hline \multicolumn{2}{|c|}{ ArticleInfo } \\
\hline \hline ArticleID & $:$ & 4813 \\
\hline \hline ArticleDOI & $:$ & $10.1186 /$ gb-spotlight-20030717-01 \\
\hline \hline ArticleCitationID & $:$ & spotlight-20030717-01 \\
\hline \hline ArticleSequenceNumber & $:$ & 165 \\
\hline \hline ArticleCategory & $:$ & Research news \\
\hline ArticleFirstPage & $:$ & 1 \\
\hline \hline ArticleLastPage & $:$ & 2 \\
\hline \hline & & RegistrationDate : 2003-7-17 \\
\hline ArticleHistory & $:$ & OnlineDate \\
\hline \hline ArticleCopyright & $:$ & BioMed Central Ltd2003-7-17 \\
\hline \hline ArticleGrants & $:$ & \\
\hline \hline ArticleContext & $:$ & 130594411 \\
\hline \hline
\end{tabular}




\section{Andrea Rinaldi}

Email: rinaldi@unica.it

Detection and prevention of viral infection and tumor induction are key to maintaining host integrity, and both rely on a variety of molecular parties. p53 is a potent tumor suppressor and a common denominator in human cancer. It transmits signals generated by cellular stresses - including DNA damage - to genes and factors that ultimately induce cell death. Interferons (IFNs) are a family of cytokines that protect the body against viral infection. In an advanced online publication in the July 17 Nature, Akinori Takaoka and colleagues at the University of Tokyo describe a previously unreported crosstalk between p53 and IFNs in tumor suppression and antiviral immunity (Nature 2003, DOI:10.1038/nature01850).

Takaoka et al. stimulated mouse embryonic fibroblasts (MEFs) with IFN- $\alpha$ and IFN- $\beta$ and in both cases observed an induction of p53 transcription and a substantial increase in the level of the protein. INFs did not activate $\mathrm{p} 53$ directly but rather via the IFN-signaling pathway, which includes the IFNactivated transcription factor ISGF3. Examining the p53-IFNs interactions in oncogene-transformed MEFs and in human cancer cell lines treated with chemotherapy drugs, they observed that IFNs contributed to tumor suppression by inducing p 53 expression and boosting its response to stress signals, leading to an enhancement of cancer cell apoptosis. These findings also provide an explanation for the previously known but poorly understood anti-oncogenic activities of IFNs.

Thy also showed that p53 was activated in MEFs infected with vesicular stomatitis virus and that viral infection induced the $\mathrm{p} 53$ proapoptotic target genes. Virus-attacked cells underwent p53-mediated apoptosis, committing a sort of "altruistic suicide" that limited virus replication and spread. Although these results highlight the important role played by p53 in antiviral host defense, how p53 and IFNs cooperate in antiviral immunity remains poorly understood.

"Our study suggests the possible usefulness of treating human cancers with IFN- $\alpha / \beta$ in combination with chemotherapeutic drugs that activate $\mathrm{p} 53$, , conclude the authors. They suggest that such a combined therapy could permit the use of lower doses of chemotherapy drugs that would otherwise exert toxic side effects by p53-independent mechanisms.

\section{References}

1. Live or let die: the cell's response to p53

2. Interferons and the tumor cell

3. Nature, [http://www.nature.com/nature]

4. University of Tokyo, [http://www.u-tokyo.ac.jp/] 